\title{
Estimating Suspended Sediment in Rivers Using Acoustic Doppler Meters
}

\section{Key Points}

- The U.S. Environmental Protection Agency (2009) estimates that excessive sediment is the leading cause of water-quality impairment in water bodies in the United States. The cost of damages attributable to sediment is high, estimated at more than \$20 billion annually (Osterkamp and others, 2004).

- Sediment monitoring is essential to informed solutions to sediment-related issues. However, sediment monitoring by the U.S. Geological Survey (USGS) has decreased considerably over the past quarter century.

- New techniques that make use of acoustic backscatter have shown great potential for accurately and cost-effectively estimating suspended-sediment concentrations.
Monitoring sediment is important for the management of water resources. "Sediment monitoring data can be used to determine effectiveness of sediment reduction actions in the watershed and guide adaptive sediment management," states Richard Turner of the U.S. Army Corps of Engineers, Walla Walla District. "Monitoring data helps foster factbased working relationships with regulators and stakeholders, and contributes to the U.S. Army Corps of Engineers' public safety efforts and flood risk reduction."

\section{Why Is Sediment Important to Measure?}

Sediment can be transported as suspended load (moves with the flow of the river) or as bedload (rolls along the riverbed) or can be deposited on the riverbed or bank. The concepts described in this Fact Sheet focus on methods for estimating suspended sediment because it is typically the largest part of total sediment transported in a river (Meade and others, 1990). Sediment is naturally occurring and essential to supporting the ecological function of a water body. High sediment concentrations in rivers and streams, however, can be detrimental (fig. 1).

\section{How Is Suspended Sediment Measured?}

For many years, USGS scientists have collected sediment samples from multiple vertical sections in rivers using point or depth-integrating samplers. Sediment samples represent the sediment concentration in a particular river at a given point in time. To continuously estimate sediment concentrations during periods when samples are not collected, scientists develop relations between sediment concentrations and other parameters, most commonly, streamflow measured at a nearby streamgage.

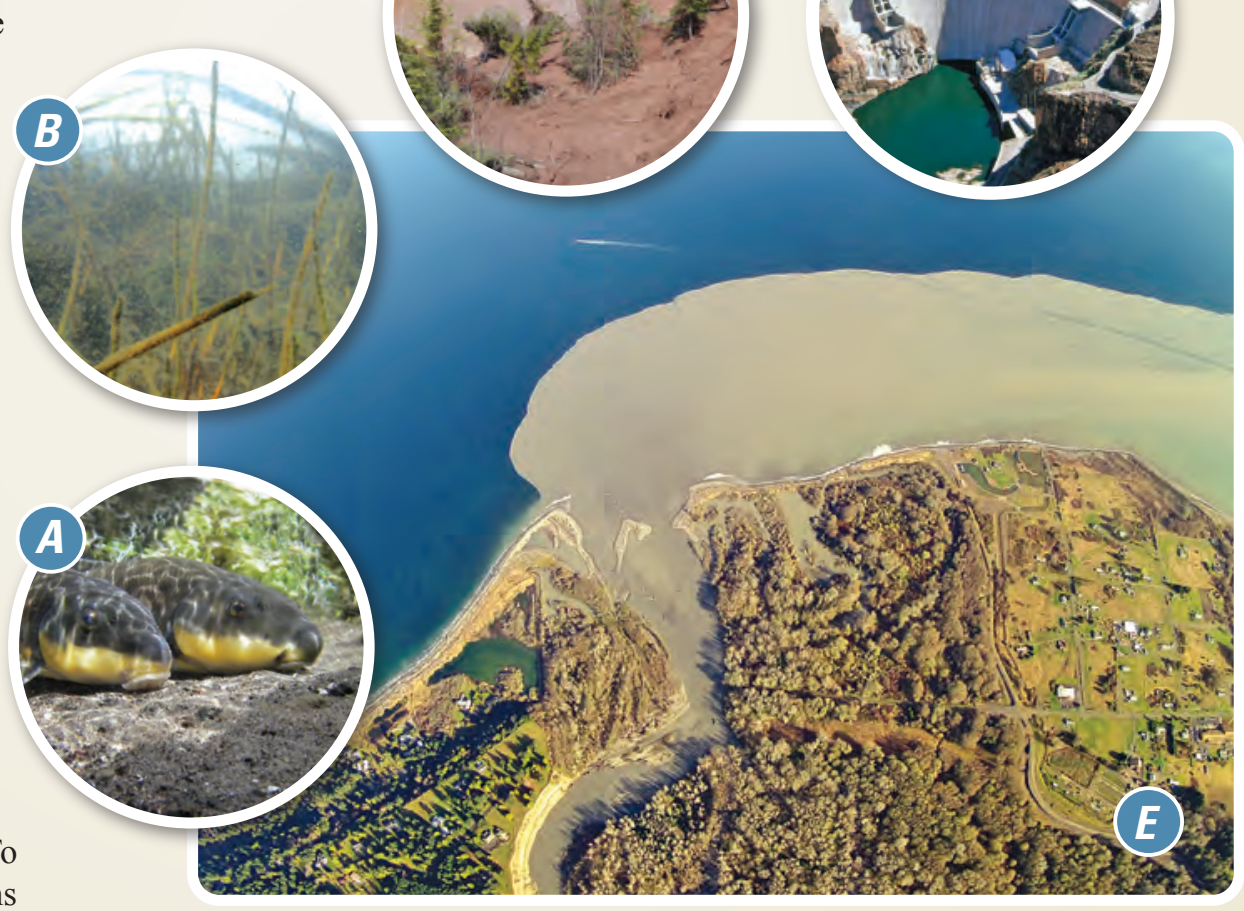

Figure 1. High sediment concentrations can reduce biological productivity of aquatic systems $(A)$, impair water quality $(B),(C),(E)$, decrease flood-protection capacity of levees and dams $(D)$, decrease reservoir storage capacity $(D)$ and affect waterway navigation $(E)$. 


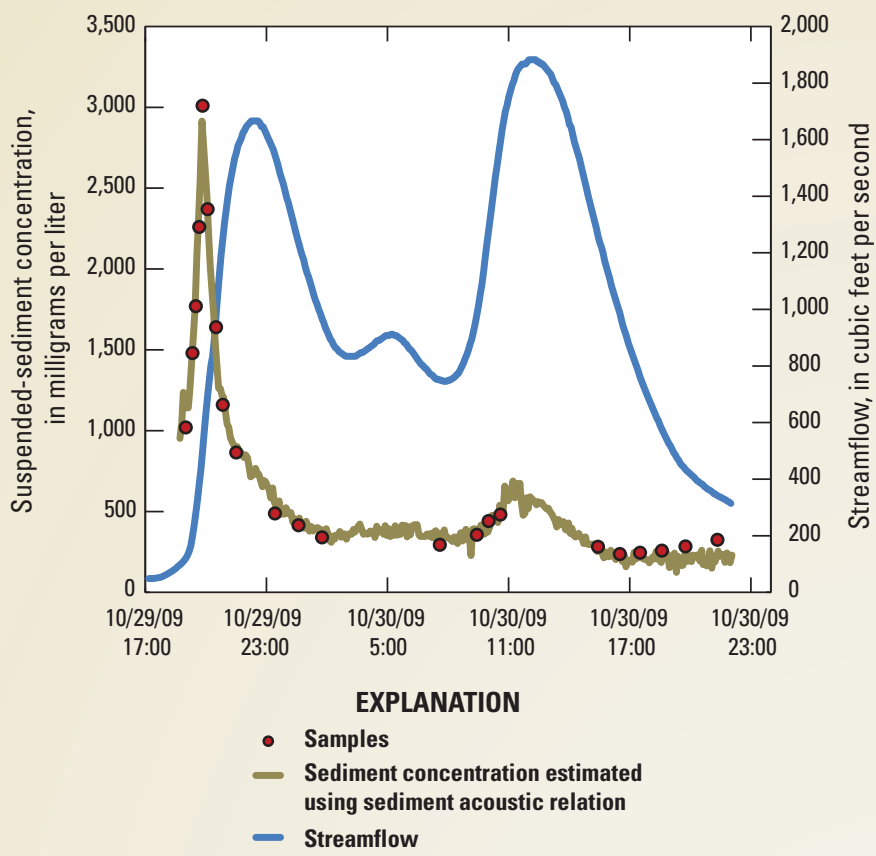

Figure 2. Suspended-sediment concentrations and streamflow during a storm event on Kickapoo Creek near Bloomington, Illinois (USGS streamgage 05579630). Sampled sediment concentrations peak prior to the peak in streamflow and are not equal at identical streamflows during the event. Sediment concentrations estimated using data from an acoustic Doppler meter at the streamgage closely match sampled concentrations.

However, this approach often does not accurately estimate sediment concentrations. Sediment concentrations may differ for the same streamflows, particularly on the rising and falling limb of the streamflow hydrograph during a storm event (fig. 2).

\section{Why Are Surrogate Technologies Useful for Estimating Suspended Sediment?}

Sediment surrogate technologies often can reliably estimate sediment concentration and typically are easier, safer, and (or) less expensive to utilize than traditional sediment data collection methods. The use of acoustic Doppler meters (fig. 3), in particular, shows great potential for estimating sediment because they:

- Are already extensively used in streamflow monitoring and provide concurrent river velocity data;

- Provide a more direct measure of sediment concentrations than the use of streamflow (fig. 2);

- Are not as susceptible to biofouling as other surrogate technologies, such as turbidity sensors;

- Measure a larger sampling volume than other surrogate technologies; and

- Can potentially provide information on sediment size if multiple acoustic frequencies are used.

Surrogate technologies allow continuous estimates of sediment concentration and load, which can be made available real-time through the USGS National Water Information System (U.S. Geological Survey, 2014). Real-time, continuous sediment data can be useful for monitoring river response downstream of areas affected by recent wildfires, construction or remediation activities, levee failures, or changing land uses. Additionally, real-time data can provide an early warning for operators of municipal water supply and hydropower facilities concerned with avoiding damage to infrastructure from sediment.

\section{How Does a Sediment Acoustic Surrogate Streamgage Work?}

Scientists deploy an acoustic Doppler meter typically at a fixed location in a river. The meter transmits pulses of sound at a known frequency, along two or more beams angled to flow, which reflect off sediment in the water (fig. 4). Acoustic Doppler meters are primarily used to measure water velocity using the Doppler principle but also output a return pulse strength indicator, called "backscatter" (Levesque and Oberg, 2012). Although backscatter is most often used to assure the quality of velocity data, it also can serve as an indicator of the concentration of sediment in the meter's measurement volume.

Scientists collect sediment samples from the river while the acoustic Doppler meter is deployed (fig. 4) and relate the sediment concentrations to backscatter measurements. The measured backscatter data are corrected for losses resulting from spreading of the acoustic beams and absorption of the pulse by water and sediment. After samples are collected over a range of hydrologic and sediment conditions, scientists develop a relation between the sediment concentrations and corrected backscatter data (fig. 5) that is used to continuously estimate sediment concentrations. Research is ongoing to evaluate the performance and operational limits of acoustic Doppler meters as a surrogate for sediment, particularly during periods of changing sediment grain-size distribution.

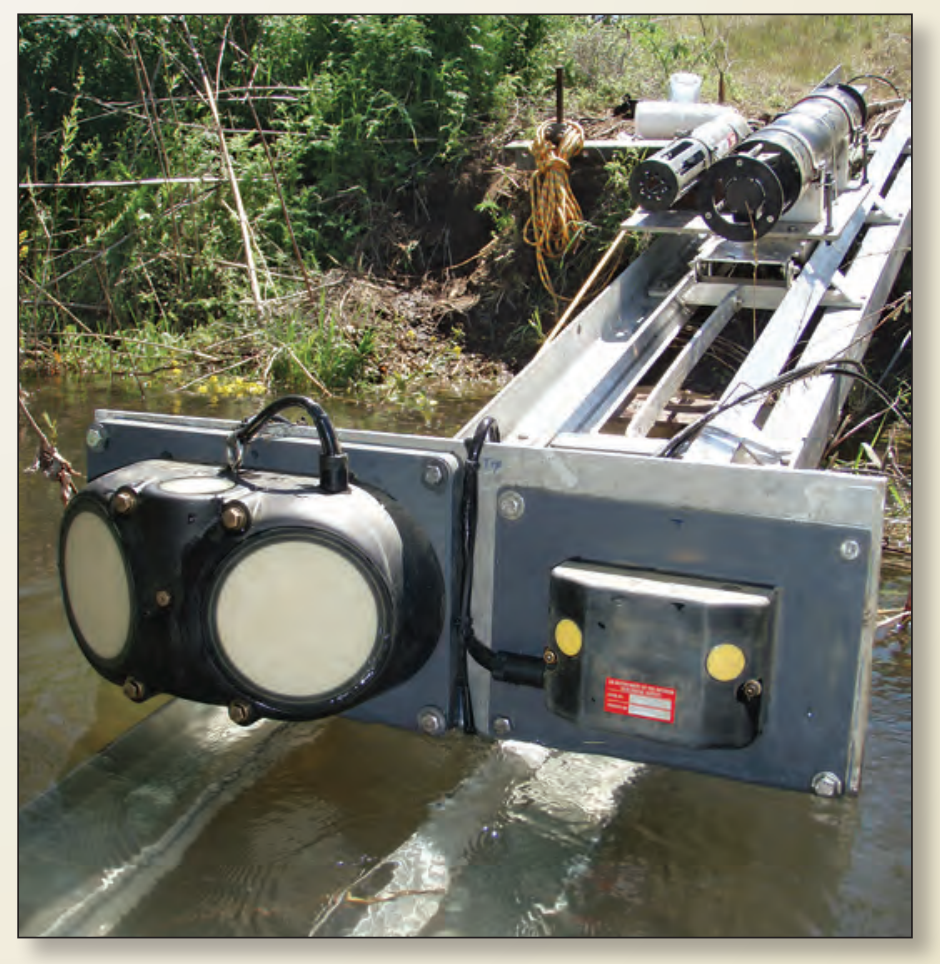

Figure 3. Acoustic Doppler meters used for estimating suspended-sediment concentrations in the Clearwater River at Spalding, Idaho (USGS streamgage 13342500). 


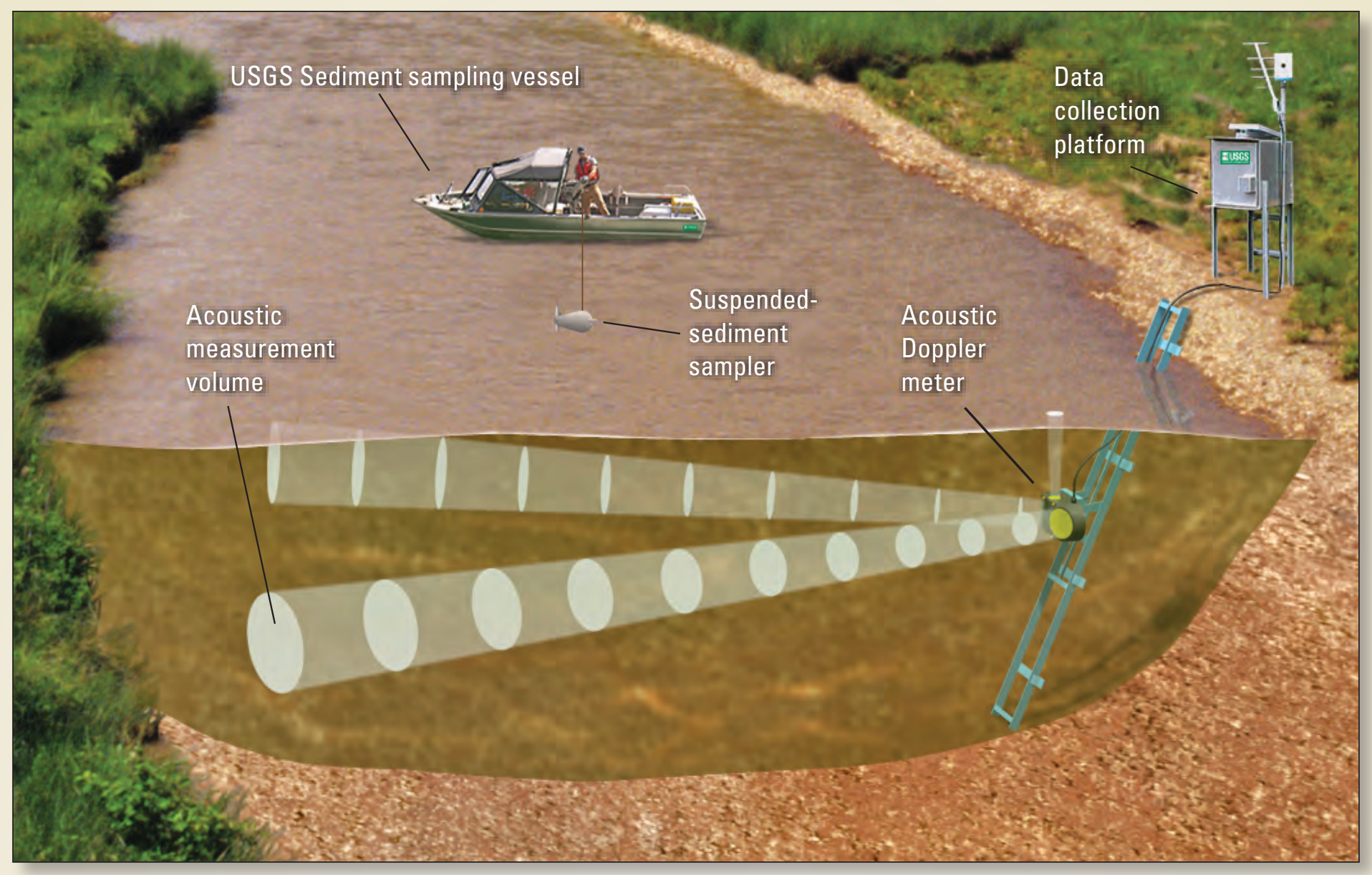

Figure 4. Example of a sediment acoustic surrogate streamgage (adapted from image provided by SonTek' ${ }^{\mathrm{TM}}$ - A Xylem Brand.)

\section{Sediment Acoustic Surrogate Monitoring in the United States}

The USGS collects suspended-sediment samples at about 673 streamgages in the United States (as of 2012). Suspended-sediment samples and acoustic Doppler meter data are concurrently collected at 115 streamgages in 22 States, and relations have been completed or are being developed at 51 of these streamgages to estimate sediment concentrations (fig. 6). As of 2012, the USGS has deployed acoustic Doppler meters in fixed locations at 470 streamgages in the United States for the purpose of monitoring streamflow. Collecting sediment samples and developing surrogate relations at these streamgages would greatly enhance a national, continuous sediment monitoring network.

\section{Want to Learn More?}

The Federal Interagency Sedimentation Project (FISP) conducts and sponsors research on emerging technologies for sediment monitoring, including the use of acoustic Doppler meters. Additionally, the USGS has created a Sediment Acoustic Leadership Team (SALT) to help guide the direction of sediment acoustic research in the United States. Learn more about FISP at http://water.usgs.gov/fisp/ and SALT at http://water.usgs.gov/osw/SALT/

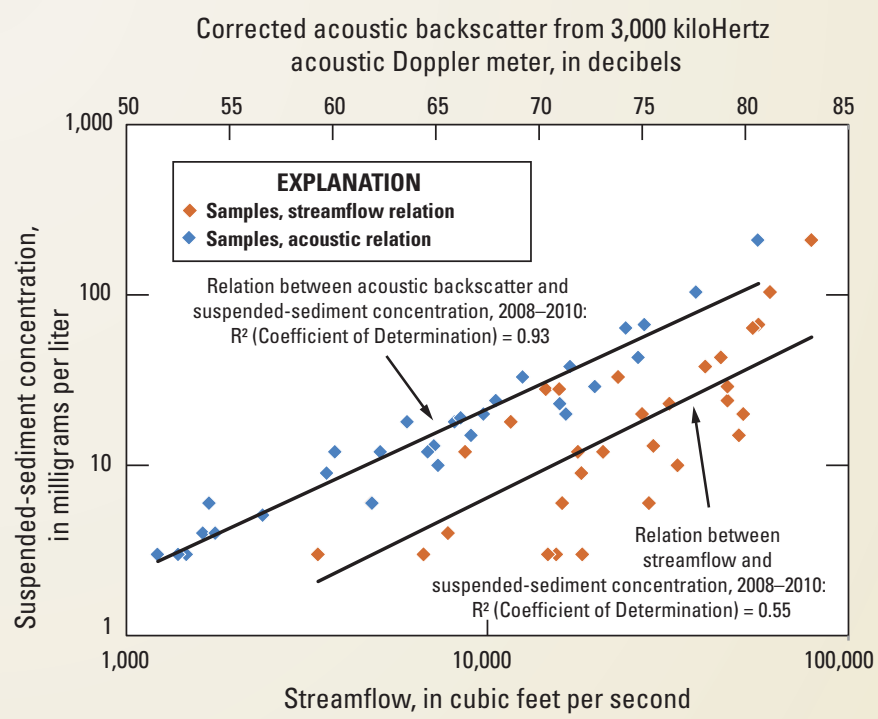

Figure 5. Relations developed between suspended-sediment concentration and streamflow, and backscatter measurements from an acoustic Doppler meter in the Clearwater River at Spalding, Idaho (USGS streamgage 13342500). The relation developed using an acoustic Doppler meter is better than the relation developed using streamflow, partially because streamflow at the streamgage comes from a combination of regulated (dammed) and unregulated (free-flowing) sources, which have varying sediment contributions. 

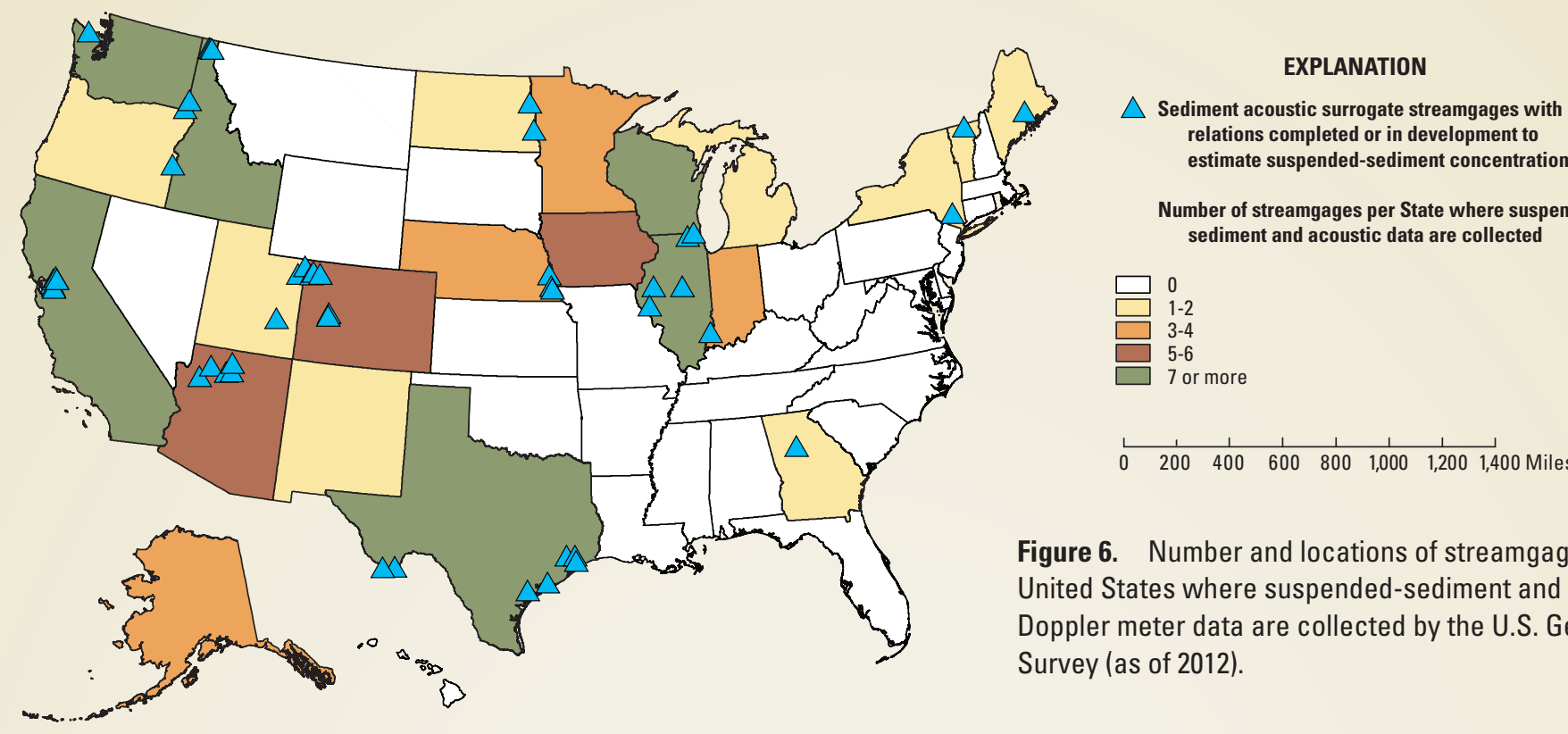
relations completed or in development to estimate suspended-sediment concentration

Number of streamgages per State where suspendedsediment and acoustic data are collected

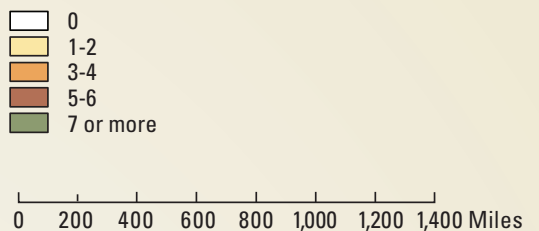

Figure 6. Number and locations of streamgages in the United States where suspended-sediment and acoustic Doppler meter data are collected by the U.S. Geological Survey (as of 2012).

\section{Sediment Acoustic Surrogate Studies of Interest}

Gray, J.R., and Landers, M.N., 2014, Measuring suspended sediment, in Ahuja, S., ed., Comprehensive Water Quality and Purification: Elsevier, Waltham, v. 1, p. 157-204.

Landers, M.N., 2012, Fluvial suspended sediment characteristics by high-resolution, surrogate metrics of turbidity, laser-diffraction, acoustic backscatter, and acoustic attenuation: Georgia Institute of Technology, School of Civil and Environmental Engineering, Atlanta, Georgia, Ph.D. dissertation, 236 p., accessed February 6, 2014, at http://hdl. handle.net/1853/43747.

Topping, D., Wright, S.A., Melis, T.S., and Rubin, D.M., 2006, High-resolution monitoring of suspended-sediment concentration and grain size in the Colorado River using laser-diffraction instruments and a three-frequency acoustic system-Proceedings of the 8th Federal Interagency Sedimentation Conference, April 2-6, 2006: Reno, Nevada, CD-ROM, ISBN 0-9779007-1-1.

Wood, M.S., and Teasdale, G.N., 2013, Use of surrogate technologies to estimate suspended sediment in the Clearwater River, Idaho, and Snake River, Washington, 2008-10: U.S. Geological Survey Scientific Investigations Report 2013-5052, 30 p., http://pubs.usgs.gov/ sir/2013/5052/.

\section{Acknowledgments}

The author wishes to thank Mark Landers, Casey Lee, Tim Straub, Kevin Oberg, and Cory Williams (U.S. Geological Survey) and Tim Calappi and Richard Turner (U.S. Army Corps of Engineers) for contributing information to this publication.

Wood, M.S., 2014, Estimating suspended sediment in rivers using acoustic Doppler meters: U.S. Geological Survey Fact Sheet 2014-3038, 4 p., http://dx.doi.org/10.3133/fs20143038.

Publishing support provided by the U.S. Geological Survey Tacoma Publishing Service Center Graphic design: Bill Gibbs

\section{References Cited}

Levesque, V.A., and Oberg, K.A., 2012, Computing discharge using the index velocity method: U.S. Geological Survey Techniques and Methods, book 3, chap. A23, 148 p., http:// pubs.usgs.gov/tm/3a23/).

Meade, R.H., Yuzyk, T.R., and Day, T.J., 1990, Movement and storage of sediment in rivers of the United States and Canada, in Wolman, M.G., and Riggs, H.C., eds., Surface water hydrology - The geology of North America: Boulder, Colo., Geological Society of America, p. 255-280.

Osterkamp, W.R., Heilman, Phil, and Gray, J.R., 2004, An invitation to participate in a North American sedimentmonitoring network: Eos, Transactions American Geophysical Union, v. 85, no. 40, p. 386-388.

U.S. Environmental Protection Agency, 2009, National water quality inventory-Report to Congress, 2004 reporting cycle, January 2009: Office of Water, Washington, D.C., EPA 841-R08-001, $43 \mathrm{p}$.

U.S. Geological Survey, 2014, National Water Information System (NWISWeb): U.S. Geological Survey database, accessed February 6, 2014, at http://waterdata.usgs.gov/nwis/.

Photographs taken by:

Figure 1E, Tom Roorda (www.RoordaAerial.com);

Figure 1C, U.S. Army Corps of Engineers-Detroit;

Figure 1D, Bureau of Reclamation;

All other photographs taken by U.S. Geological Survey employees.

Author: Molly S. Wood, Hydraulic Engineer

U.S. Geological Survey

Idaho Water Science Center

mswood@usgs.gov

For additional information, contact:

U.S. Geological Survey

Office of Surface Water

415 National Center,

12201 Sunrise Valley Drive

ISSN 2327-6916 (print) ISSN 2327-6932 (online)

Reston, Va. 20192

http://dx.doi.org/10.3133/fs20140328

http://water.usgs.gov/osw/contact.html 